\title{
Is Music Mimetic? Ricoeur and the Limits of Narrative
}

\author{
Roger W. H. Savage
}

There is certainly an art which is not mimetic, this is music. Although, at the limit, could not one say that to each piece of art there corresponds a mood?

Paul Ricoeur

In the closing pages of Time and Narrative, Paul Ricoeur remarks that as narrative attempts to draw near the inscrutability of time, it approaches its limits. Beyond the narrative art's capacity to refigure time, lyric poetry "gives a voice, which is also a song"1 to a meditation on the disproportion between the brevity and fragility of human life and the eroding power of time. The lyricism of this meditative thinking touches the fundamental element of our mortal existence without passing through the narrative art. At its limit, the mood to which this lyricism gives voice replies in its own way to the aporia of time and its other.

The intractability of this aporia sets in motion a reflection on music's mimetic relation to the fundamental experience of our nonmastery of time. As the narrative genre "overflows into other genres of discourse that, in their own ways, undertake to speak of time," this fundamental experience makes itself felt beyond the limit of narrative configurations. The "echoes of the sempiternal elegy" that remain dissimulated at several places in Ricoeur's text "under the modesty and sobriety of prose" 3 bear witness to another transcultural form of necessity which, like the narrative art, replies to the aporetics of temporality. Yet unlike narrative, which for Ricoeur is an imitation of action, this other transcultural form of necessity redescribes poetically 
the experience of being-affected that is the mark of our finitude and the condition of our openness to the world.

The paradox Ricoeur attributes to the production in works of art of moods and feelings that have no prior reference to the real provides a starting-point for exploring his claim that music is an art that is not mimetic. Ricoeur's qualification that each piece of art has its mood suggests that the force of this paradox extends beyond narrative's refiguration of reality. This paradox, in which the work's suspension of the real is the condition for its refiguration of it, gives the full measure of mimesis. Through discovering dimensions of experience that did not previously exist, the work augments the real by renewing it in accordance with itself. The further the work distances itself from the real, the deeper its bite. Accordingly, the truth of the work consists in the "capacity of the work to break a path in the real by renewing the real in accordance with the work." ${ }^{4}$ By raising action above itself, narrative's epoché of the real opens the way to the real's mimetic transfiguration. Correlatively, with the break with painting's representational function in the twentieth-century, the expressive function of the world created by a work becomes fully deployed. Ricoeur opines that music goes further than even nonfigurative painting in its power of redescription. Without representing anything of the real, a piece of music possesses a tone or mood that it establishes in us. ${ }^{5}$

Arnold Schoenberg's music is exemplary in this regard: by renouncing a tonal center, Schoenberg's Die bängenden Garten, Erwartung and Pierrot lunaire give expression to realms of feeling that resonate with the loss of credibility of the sense of temporal unity imposed by tonal closure. By dispensing with the "merely nomic generalities [of nineteenth-century compositional practices] that hid the genuine relation to the mood that each piece expresses," these works reveal music's essential significance in much the same way as nonfigurative painting discloses figurative art's fundamentally mimetic character. By abolishing the traditional requirement that dissonances resolve, Schoenberg's negation of familiar means of musical expression achieves a break comparable to "Picasso's nonfigurative style, where the human figure is cut, [and] twisted." Through abandoning the tonal conventions that facilitate access to traditional, tonal works, each of Schoenberg's atonal works achieves its communicability through its unique singularity. This intensification of the mood or feeling possessed by each work "forbids any recourse to attached rules defining a priori what is to be beautiful." For Ricoeur, the naked singularity of each work's expression of its 
tone is what can make contemporary art so difficult to understand. Despite the challenges it presents, Schoenberg's music bears out the paradox that the more a work retreats from the real, the more intense is its return and the greater is its bite; the communicability of the moods or tones in Schoenberg's expressionistic compositions augments the real by refiguring the affective dimension of our experiences. ${ }^{7}$

\section{Music as Nonrepresentational Art}

Ricoeur's suggestion that Schoenberg's music explores new realms of feeling cuts across a long-standing problematic within the discourse of absolute music. Absolute music is "pure" instrumental music that has no programmatic content or associations. Richard Wagner used the term to justify his claim that the "total work of art" (Gesamtkunstwerk) represented the apogee of the Germanic symphonic tradition. ${ }^{8}$ According to romantic sensibilities, instrumental music's lack of a concept or object signifies its freedom from, or dependence upon, all constraining references. Consequently, its nonrepresentational status signifies the metaphysical dignity invested in it as a "language beyond language." This investment in absolute music in the nineteenth century consummates a historic reversal of judgment in which music's deficiency with respect to its representational power becomes the symbol of its sublime ineffability. Within this schema, absolute music's transcendence of reality is the correlative opposite of its imitative, representational function.

The Romantic reversal of judgment stands in a long tradition in which the idea of absolute music supplants the principle of music's mimetic dependence upon language. Carl Dahlhaus argues that by setting music against language "as the expression of human reason," the understanding of music that originates in antiquity lays the cornerstone for mimetic theories. According to this understanding, music (musiks) is the unity of harmony (barmonia), rhythm (rhythmos) and language (logos). Separating harmony and rhythm from language reduces musikç to a shadow of its quintessential nature. Seemingly stripped of reason, purely instrumental music becomes subordinate to the discursive power of language. By identifying the meaning of purely sonorous figurations with the imitation of speech intonation, of feelings and affects, and, in the late twentieth- and twenty-first century, of social practices, ideological constructs and political agendas, mimetic theories of music redress the perceived deficiencies of instrumental music's 
nonrepresentational significance with substantive interpretations of its concrete content.

The advent of the seconda prattica in the early seventeenthcentury evidences the preeminence of the humanistic intention to place music under the logos of ordinary speech. Through rejecting the idea that music is an imitation of the divine logos, Vincenzo Galilei along with other members of the Camarata intended to wrest music's clarity of meaning from reason's subjugation to purely sensuous displays of sound. The monodic-harmonic style cultivated by proponents of the seconda prattica promoted textual clarity in accordance with the Platonic precept that the "mode and rhythm must fit the words." 10 Through imitating the manner of their intonation in speech, musical representations of such feelings in a stile rappresentativolay the foundation for a theory of musical rhetoric that dominates the Baroque doctrine of aesthetic affects. The representation of affects by descending minor seconds, tonal ambiguity, or ascending leaps, for example, identified these musical figures with expressions of grief (passus duriusculus), doubt (dubitatio) or exclamation (exclamatio). These figures' rhetorical function codifies the principle of imitation advanced by the seconda prattica's promotion of its humanistic ideals.

E.T.A Hoffman consecrates the reversal of judgment that elevates instrumental music's poetic essence above language when, in his review of Beethoven's "Fifth Symphony," he celebrates Beethoven's genius in mastering the heights of musical expression. As a "completely romantic composer," Beethoven's instrumental music "discloses ... a world that has nothing in common with the external sensual world that surrounds him, a world in which he leaves behind all definite feelings to surrender himself to an inexpressible longing." Accordingly, Beethoven's symphonic work surpasses the limits of vocal music, which for Hoffman and his contemporaries excludes "the character of indefinite longing, merely representing emotions defined by words as emotions experienced in the realm of the infinite" by means of a language that is immediately accessible only to feeling. Invested with metaphysical dignity by the gnostic function of its sublime ineffability, absolute music gives voice to the somnambulistic power of imagination that evidences the vitality of the composer's inner psychic life. ${ }^{11}$

The romantic contention that absolute music leaves the world behind motivates narratological interpretations that identify music's internal processes with extra-musical social and political agendas. By transposing Hermann Kretzschmar's hermeneutical methods onto a 
socio-cultural plane, musicologist Susan McClary relates the narrative strategies she identifies with tonality and sonata form with the hegemony of a patriarchal order. Kretzschmar's antipathy to Eduard Hanslick's formalist aesthetics prefigures McClary's deconstructions of absolute music. ${ }^{12}$ In her view, absolute music only appears "to make itself up without reference to the outside world ... [because] it adheres so thoroughly to the most common plot outline and the most fundamental ideological tensions available within Western culture." ${ }^{13}$ Consequently, the interlocking schemata of tonality and the traditional sonata form constitute the framework of a master narrative that enacts a hegemonic political agenda. The pretense of music's formal purity obscures the socially constructed representations of gender identities, sexual promiscuity and exoticized Other that she argues coincide with the ideological containment and marginalization of differences. The double gesture that confines these differences by means of the subjugating strategy of absolute music's master narrative puts the Other on display. According to her, tonality's discursive force frames the contagion of the Other as an object of surveillance and fascination. Hence, the representation of a substantive social content constitutes the mimetic reproduction of a real political agenda dissimulated by the metaphysical pretense of absolute music's transcendent autonomy.

\section{The Poetics of Narrativity}

By relegating absolute music to the ideological preserve of the cult of art-religion, the discourse of absolute music effectively eclipses music's rootedness in experiences that demand to be expressed. Narrativizing interpretations that identify music's substantive content with the emplotment of a succession of events evoke the specter of a musical hermeneutics whose methods and strategies decipher socially encoded representations of sexuality, gender and racial differences. Shifting music's imitative function onto the social plane combats the pretense of music's aesthetic self-sufficiency at the expense of music's capacity to invent new worlds that individual works express, thereby eclipsing the paradox at the heart of the poetic activity that constitutes the work.

According to Ricoeur, "as the inversion of ordinary language, poetic language is not directed outwards, but inwards towards an interior, which is nothing other than the mood structured and expressed by a poem." The suspension of ordinary or ostensive references, which 
this inversion effects by redirecting a work's reference to the world it expresses, is the negative condition of the work's power to redescribe reality. In this respect, "a poem is like a work of music in that its mood is exactly coextensive with the internal order of symbols articulated by its language." 14 There is no creative imitation of reality apart from the poetic activity that invents new allusions to the real by creating the world of the work. Mimesis and poiesis are joined together in a work of imagination in which the "idea" (dianoia) that a work expresses is attributable to the synthetic operation that schematizes the "thought" the work presents as a temporal whole.

The mediating role that plot plays foregrounds narrative's privileged relation to the time of action. Moreover, the fact that "narratives have acting and suffering as their theme"15 evinces the anchorages of narrative activity in the practical field of our experiences. By raising human action above itself, the imitation of action in the realm of fiction transvalues ethical understandings of actions, characters and events. The poetic transformation of human action and suffering through stories that recount actions and events effects the mimetic displacement of ethics to poetics. ${ }^{16}$ This mimetic displacement of praxis from the ethical to the poetic realm finds its completion in fiction's refiguration of the practical field of our experiences.

Ricoeur's contention that, of all the arts, music is the one that is not mimetic finds its initial justification in the claim that mimesis is an action about action. And yet, the confession of the limits of narrative indicates a place for a mode of poiesis in which the pathos of experiences of passivity finds a voice. In his retrospective remarks at the end of Time and Narrative, he comments that the "lyricism of meditative thinking goes right to the fundamental without passing through the art of narrating." ${ }^{17}$ As the multiplication of our experiences of eternity in fiction brings narrative to its limits, the fundamental experience of being-affected by time gives rise to other replies to the enigma of time and its other. ${ }^{18}$ At this limit, the evocation in music of feelings or moods that have no prior existence in reality answers to the aporia of time's inscrutability by redescribing affective dispositions that open us to the world.

\section{Is Music Mimetic?}

The notion that this evocation of feelings and moods is the sign of a Romantic sensibility, in which music's ineffability is the index 
of its transcendent value, occludes the horizon of music's ontological vehemence. Critical strategies that unmask absolute music's complicity with the hegemonic representations of gender, sexuality and exoticized Others eclipse this paradox: a work's distance from the real is directly related to the bite the work exerts on it. This paradox explodes the justificatory schema of a form of criticism that shifts the topos of art's imitation of nature onto the social plane. By supplanting the idea that art or music reproduces an existing thing, the paradox that a work's suspension of the real is the condition for its redescription opens a path that leads beyond the poetic conceit that absolute music speaks a "language beyond language" to the expression of a world that reverberates with its unique tone.

The objection that music's expression of a feeling or mood is a remnant of the nineteenth century's cult of art religion overlooks the fact that the tone or mood of a work has an ontological significance. Moods and feelings anchor our sense of participating in the world to which we belong by attuning us to it. As a "state-of-mind," mood delivers the fact of our being over to the manner in which we inhabit the world. According to Heidegger, mood is equiprimordial with understanding in that it discloses this manner of being "prior to all cognition and volition, and beyond their range of disclosure." ${ }^{19}$ By bringing the fact of our existing in the world before us, our states-ofmind reveal how our attunement to the world is a condition for our engagement with it. We only "encounter something that matters to us" in having a state-of-mind. This state-of-mind, which "implies a disclosive submission to the world," also opens us to it. ${ }^{20}$ By assailing us, the mood in which we find ourselves disposed toward the world and others makes it possible to direct ourselves toward it and them.

By identifying mood with the attunement of a state-of-mind to a world that we inhabit with others and filled with objects and things, Heidegger's existential-ontological analysis frees music's affective quality from theories of expression in which expression is the representation of emotions embodied in music. To the extent that having a state-ofmind is the condition for encountering the world at all, the possibility of having a world depends on the fact that we first encounter the world in the way we are disposed toward it. Correlatively, the idea that poetic discourse aims at expressing feelings and moods that have no prior referent in reality links music's nonrepresentational status with a work's ontological vehemence. For Heidegger, in "poetical discourse, the communication of the existential possibilities of one's state-of- 


\section{ROGER W.H. SAVAGE}

mind can become an aim in itself, and this amounts to a disclosing of existence." ${ }^{21}$ The exploration in music of singular feelings and moods opens the world to us anew. In turn, the poetic redescription of our inherence in the world by moods and feelings created by individual works augments the affective depths of our human finitude.

The recovery of feeling's poetic quality from the ruinous opposition between knowledge's denotative and art's connotative functions shifts the burden of a theory of music's communicability from decoding a content contained within music's formal features and structural processes to explicating the experience of the fit between a work and its expression. By giving a figure to feelings, the exemplification in music of singular moods and feelings anchors music in dimensions of our experiences that precede the objectification of reality. In this light, music's nonrepresentational character is the correlate of its mimetic relation to the affective field in which our experiences of belonging to the world are anchored.

The idea that, of all the arts, music is the one that is not mimetic bears out the difference between music's relation to this affective field and narrative's imitation of action. By resisting the assimilation of music to narrative, Ricoeur indicates the place of music's depiction of feelings and moods in relation to the practical field of our experiences. By constructing worlds of "singular essences in the realm of feeling," 22 individual works push back the boundaries of our affective experiences by modulating our elective affinities with the world. Unlike the act of knowing, which gives rise to the subject-object duality, feeling manifests "a relation to the world that constantly restores our complicity with it." 23 According to Ricoeur, feeling unites an "intention toward the world and an affection of the self." ${ }^{24}$ Consequently, feeling's general function is to interiorize the reality that we objectify over against ourselves in coming to know and master reality. By suspending ordinary feelings and emotions, poetic feelings augment this affective dimension of our experiences by assimilating us to the meaning displayed by a metaphor, poem or musical work. Through this epoché of bodily emotions where, according to Ricoeur we otherwise "live" our bodies in a more intense way, poetic feelings accompany and complete the work of imagination by making the thought (dianoia) schematized by a work our own. ${ }^{25}$ The mood structured by a poem or musical work raises ordinary emotions and feelings above themselves by means of their poetic transposition; the ontological vehemence of this poetic transposition of feeling acquires its full force through our re-attunement to the world. 


\section{Music and the Limits of Narrative}

The fact that the "elevation of feeling to fiction is the condition of its mimetic use" 26 conjoins a reflection on the limits of narrative to one on music's significance with respect to the experiences of nonmastery that inhere in the condition of human finitude. For Ricoeur, the multiplication of limit-experiences "worthy of being placed under the sign of eternity" ${ }^{27}$ stems from the singular quality each work unfolds: "it is in a different possible world that time allows itself to be surpassed by eternity." 28 As the art of narration draws near the inscrutability of time, and as "time, escaping our will to mastery, surges forth on the side of what, in one way or another, is the true master of meaning," 29 the imaginative explorations of our being-affected, which Ricoeur suggests occurs in music in a pure state, reply in their own ways to the enigma of time's ultimate unrepresentability. ${ }^{30}$ Beyond the limit of tales of time and the other of time, music's redescription of our elective affinities with the world bears witness to the ontological difference attested by the aporia of time's inscrutability. ${ }^{31}$

Music takes its measure of time's ultimate inscrutability through its mimetic refiguration of the depths of feeling that arise in response to this difference. In his reflections on our affective fragility, Ricoeur remarks that "“[m]oods' alone can manifest the coincidence of the transcendent, in accordance with intellectual determinations, and the inward, in accordance with the order of existential movement." 32 The height of the feeling that replies to the demand by reason for the Unconditioned attests to the difference between being and beings:

If being is that which beings are not, anguish is the feeling par excellence of ontological difference. . . . Joy attests that we have a part of us linked to this very lack of being in beings. That is why Spiritual Joy. . . designate[s] . . the only affective 'mood' worthy of being called ontological. Anguish is only its underside of absence and distance. If man is capable ... of Joy in and through anguish, that is the radical principle of all 'disproportion' in the dimension of feeling and the source of man's affective fragility. ${ }^{33}$

This principle authorizes the mimesis in music of the radical passivity evidenced by the enigma of time and its other. Through its poetic redescriptions of the disproportion in the dimension of feeling between our part in being and the lack we experience in the face of our 


\section{ROGER W.H. SAVAGE}

nonmastery of time, music expresses the pathos and joy of our mortal dwelling.

University of California, Los Angeles

\section{Notes}

${ }^{1}$ Paul Ricoeur, Time and Narrative vol. 3, trans. Kathleen McLaughlin and David Pellauer (Chicago: University of Chicago Press, 1988), p. 273.

${ }^{2}$ Ricoeur, Time and Narrative vol. 3, p. 271.

${ }^{3}$ Ricoeur, Time and Narrative vol. 3, p. 271.

${ }^{4}$ Paul Ricoeur, Critique and Conviction, trans. Kathleen Blamey (New York: Columbia University Press, 1998), pp. 173 -174.

${ }^{5}$ Ricoeur, Critique and Conviction, p. 172 ff; see Paul Ricoeur, Time and Narrative vol. 1, trans. Kathleen McLaughlin and David Pellauer (Chicago: University of Chicago Press, 1984).

${ }^{6}$ Ricoeur, Critique and Conviction, p. 181. For Ricoeur, "the elimination of tonality in Schönberg's Pierrot lunaire, then the invention of the twelvetone system in his later works, achieves, in relation to the tempered scale used throughout the eighteenth and nineteenth centuries the same break with familiarity as Picasso's nonfigurative style, where the human figure is cut, twisted, in comparison with the figurative style of Delacroix. The musical rules of the nineteenth century had nothing universal about them. As in painting, the convention of the rules facilitated access to the works; communicability was not accomplished through singularity alone. And this is why very contemporary art is so difficult: it forbids any recourse to attached rules defining a priori what is to be beautiful."

${ }^{7}$ Ricoeur, Critique and Conviction, p. 176. Ricoeur maintains that "[a]s the representational function is lessened-this is the case with nonfigurative painting and with music when it is nondescriptive - as the gap with reality grows wider, the biting power of the work on the world of our experience is reinforced."

${ }^{8}$ See Carl Dahlhaus, The Idea of Absolute Music, trans. Roger Lustig (Chicago: Chicago University Press, 1989), p. 18. According to Dahlhaus, Wagner first used the term "absolute music" in 1846 in his program to Beethoven's Ninth Symphony. Wagner singles out Beethoven as anticipating the total work of art when, having explored "unheard-of possibilities of absolute tone-speech," Beethoven in his Ninth Symphony anchors symphonic music in the defining word (Richard Wagner, Richard Wagner's Prose vol. 1: The Art-Work of the Future, trans. William Ashton Ellis (New York: Broude Brothers, 1892), pp. 125-126). Accordingly for Wagner, absolute music's emancipation 
from poetry and dance was a negative but necessary step in the aesthetic and historical development of the Gesamtkumstwerk.

${ }^{9}$ Carl Dahlhaus, The Idea of Absolute Music, p. 8.

${ }^{10}$ Plato, Republic, trans. G. M. A. Grube (Indianapolis: Hacket Publishing, 1992), p. 74 [398d].

${ }^{11}$ E.T.A. Hoffman, Beethovens Instrumentalmusik (1813). In Edward A. Lippman, ed. Musical Aesthetics: A Historical Reader vol. 2 (Stuyvesant: Pendragon Press, 1988), pp. 210 - 211. See Hans-Georg Gadamer Truth and Method, 2nd revised ed., trans. Joel Weinsheimer and Donald G. Marshall (New York: Crossroad Publishing Co. 1989), p. 73.

${ }^{12}$ Hermann Kretzschmar, "Suggestions for the Furtherance of Musical Hermeneutics," in Musical Aesthetics: A Historical Reader, vol. 3, ed. E. A. Lippman (New York: Pendragon Press, 1990 [1902]); Hermann Kretzschmar, "New Suggestions for the Furtherance of Musical Hermeneutics: The Aesthetics of Musical Compositions," Musical Aesthetics: A Historical Reader, vol. 3, ed. E. A. Lippman (New York: Pendragon Press, 1990 [1905]).

${ }^{13}$ Susan McClary, "Narrative Agendas in 'Absolute Music': Identity and Difference in Brahms's Third Symphony," Musicology and Difference: Gender and Sexuality in Musical Scholarship, ed. Ruth A Solie (Berkeley: University of California Press, 1993), p. 333. McClary argues that tonality "operates according to a standard sequence of dynamic events, giving the music it organizes a distinctly narrative cast" (p. 330). Sonata form throws this standardized tonal procedure into relief. By identifying the first theme of the sonata form with the paradigmatic position of the masculine protagonist and the second theme with that of the feminine Other, McClary denounces absolute music's claim to aesthetic autonomy by unmasking the semiotics of gender encoded within this form's tonal structure. From the vantage-point of this cultural semiotics, reprising these two themes in the tonic key achieves closure at the expense of the feminine Other's identity. By depicting the implied protagonist's assertion of his identity as a natural imperative, this tonal schema conceals the absolutist political narrative it enacts.

${ }^{14}$ Paul Ricoeur, Interpretation Theory: Discourse and the Surplus of Meaning (Fort Worth: Texas Christian University Press, 1976), p. 59.

${ }^{15}$ Ricoeur, Time and Narrative vol. 1, p. 56.

${ }^{16}$ Ricoeur, Time and Narrative vol. 1, p. 47. According to Ricoeur, "if we are to talk of a 'mimetic displacement' or a quasi-metaphorical 'transposition' from ethics to poetics, we have to conceive of mimetic activity as a connection and not just as a break. It is in fact the movement from mimesis $_{1}$ to mimesis. It is beyond doubt that the term muthos indicates discontinuity, the word, praxis, by its double allegiance, assures continuity between the two realms of action-ethics and poetics" (p. 47). See Paul Ricoeur, Oneself as Another, trans. Kathleen Blamey (Chicago: University of Chicago Press, 1992), p. 164. 


\section{ROGER W.H. SAVAGE}

${ }^{17}$ Ricoeur, Time and Narrative vol. 3, p. 273. Ricoeur prefaces this claim by commenting that "[s]ometimes the impression prevailed of a complicity between the nonmastery inherent in our throwness and fallenness, and that other nonmastery recalled to us by the contemplation of the sovereign movements of the stars; sometimes, on the contrary, the feeling prevailed of the incommensurability between the time allotted mortals and the vastness of cosmic time. In this we found ourselves buffeted back and forth between the resignation engendered by the collusion between these two forms of nonmastery and the grief that is ceaselessly reborn from the contrast between the fragility of life and the power of time that destroys."

${ }^{18}$ Ricoeur, Time and Narrative vol. 3, pp. 270 - 271. For Ricoeur, it now "is a question of the ... limits of such a refiguration of time by narrative. ... By an internal limit, we mean that the art of narration exceeds itself to the point of exhaustion, in attempting to draw near the inscrutable. By an external limit, we mean that the narrative genre itself overflows into other genres of discourse that, in their own ways, undertake to speak of time."

${ }^{19}$ Martin Heidegger, Being and Time, trans. John Macquarrie and Edward Robinson (New York: Harper \& Row, Publishers, 1962), p. 175. Original emphasis. From this standpoint, "[p]henomenally, we would wholly fail to recognize both what mood discloses and how it discloses, if that which is disclosed were to be compared with what Dasein is acquainted with, knows, and believes 'at the same time' when it has such a mood." Accordingly, from "the existential-ontological point of view, there is not the slightest justification for minimizing what is 'evident' in states-of-mind, by measuring it against the apodictic certainty of a theoretical cognition of something which is purely present-at-hand."

${ }^{20}$ Heidegger, Being and Time, p. 177. Original in italics.

${ }^{21}$ Heidegger, Being and Times p. 205; see Paul Ricoeur, The Rule of Metaphor: Multidisciplinary Studies of the Creation of Meaning in Language, trans. Robert Czerny (Toronto: University of Toronto Press, 1977), pp. $221 \mathrm{ff}$.

${ }^{22}$ Ricoeur, Critique and Conviction, p. 174; see Ricoeur, "Arts, Language and Hermeneutic Aesthetics" (http://www.philagora.net/philo.fac/ricouer).

${ }^{23}$ Paul Ricoeur, Fragile Man, trans. Charles A. Kelbley (New York: Fordham University Press, 1986), p. 85.

${ }^{24}$ Ricoeur, Fragile Man, p. 89; see ff.

${ }^{25}$ See Paul Ricoeur, "The Metaphorical Process as Cognition, Imagination and Feeling," On Metaphor, ed. Sheldon Sacks (Chicago: Chicago University Press, 1978), p. 154. For Ricoeur, "this instantaneous grasping of the new congruence is 'felt' as well as 'seen.' By saying that it is felt, we underscore the fact that we are included in the process as knowing subjects. If the process can be called, as I called it, predicative assimilation, it is true that we are assimilated, that is, made similar to what is seen as similar. This selfassimilation is a part of the commitment, proper to the 'illocutionary' force 


\section{IS MUSIC MIMETIC?}

of the metaphor as speech act. We feel like what we see like.... To feel, in the emotional sense of the word, is to make ours what has been put at a distance by thought in its objectifying phase. Feelings, therefore, have a very complex kind of intentionality. They are not merely inner states but interiorized thoughts. It is as such that they accompany and complete the work of imagination as schematizing a synthetic operation: they make the schematized thought ours. ... Feeling is not contrary to thought. It is thought made ours. This felt participation is a part of its complete meaning as a poem."

${ }^{26}$ Paul Ricoeur, Rule of Metaphor, p. 245. Accordingly, the "phenomenological objectivity of what commonly is called emotion or feeling is inseparable from the tensional structure of the truth of metaphorical statements that express the construction of the world by and with feeling. The possibility of textural reality is correlative to the possibility of a metaphorical truth of a poetic schematization; the possibility of one is established at the same time as that of the other" (p. 255). In Ricoeur's view, mood is the "hypothetical created by the poem ... that, as such, occupies the place in lyric poetry that muthos occupies in tragic poetry." Hence, lyric muthos "is joined by a lyric mimesis, in the sense that mood created in this fashion is a sort of model for "seeing as' and 'feeling as"' (p. 245).

${ }^{27}$ Ricoeur, Time and Narrative vol. 3, p. 271.

${ }^{28}$ Ricoeur, Time and Narrative vol. 3, p. 271.

${ }^{29}$ Ricoeur, Time and Narrative vol. 3, p. 261.

${ }^{30}$ Ricoeur, Time and Narrative vol. 3, p. 271; see Ricoeur, Critique and Conviction, p. 174.

${ }^{31}$ Ricoeur, Time and Narrative vol. 3. In the closing pages of this final volume, Ricoeur comments that the distinction Heidegger draws between the temporal and temporalizing has but a single function, which is to point to the ontological difference between Being and beings. This difference evidences the radical nature of human finitude by indicating temporality's inscrutable character: "Apart from this role, it [the ontological difference between Being and beings] only succeeds in indicating the inscrutable character of temporality understood as the wholeness of Dasein. For, taken by itself, the distinction between temporal-being and temporality no longer designates a phenomenon accessible to hermeneutic phenomenology as such" (p. 270).

${ }^{32}$ Ricoeur, Fallible Man, p. 106.

${ }^{33}$ Ricoeur, Fallible Man, p. 106. Original emphasis. Ricoeur explains that "[i]f being is 'beyond essence,' if it is horizon, it is understandable that the feelings that most radically interiorize the supreme intention of reason might themselves be beyond form..... The height of the feeling of belonging to being ought to be the feeling in which what is most detached from our vital depth — what is absolute, in the strongest sense of the word-becomes the heart of our heart. But then one cannot name it; one can merely call it the Unconditional that is demanded by reason and whose inwardness is manifested by feeling" (pp. 105-106). 